\title{
Neurological Disease and Marriage
}

\author{
Nörolojik Hastalık ve Evlilik \\ Tuba Aydın ${ }^{1}$, Mehmet Emin Onger ${ }^{1,2}$ \\ ${ }^{1}$ Department of Neuroscience, Health Sciences Institute, Ondokuz Mayis University, Samsun-TURKEY \\ ${ }^{2}$ Department of Histology and Embryology, Medical Faculty, Ondokuz Mayis University, Samsun-TURKEY \\ Yazışma Adresi / Correspondence: \\ Mehmet Emin Onger \\ Histology and Embryology, Medical Faculty, Samsun, Turkey \\ T: +903623121919 / $2934 \quad$ E-mail: mehmetemin.onger@gmail.com \\ Geliş Tarihi / Received : 25.07.2020 Kabul Tarihi / Accepted : 30.10.2020 \\ Orcid: \\ Tuba Aydin https://orcid.org/0000-0001-9096-4521 \\ Mehmet Emin Onger https://orcid.org/0000-0001-8922-9642 \\ ( Sakarya Tip Dergisi / Sakarya Med J 2020, 10(4):705-710 ) DOI: 10.31832/smj.773874
}

\begin{abstract}
Marriage affects people's happiness and lifetime. Researches support the idea that married people are healthier and happier and they have longevity than other people (single, divorced and widowed). In the world, incidence of neurological diseases increases day by day and they may affect patients, their families and societies. However, marital status, marital relationship, and spouse's situation affect illness acceptance and cope with illness. In the literature, it is stated that married patients are healthier and have long life span than other patients with neurological diseases such as Amyotrophic Lateral Sclerosis (ALS), Multiple Sclerosis (MS), Alzheimer Disease (AD), Parkinson's Disease (PD) and stroke. On the other hand, diseases such as MS and epilepsy may be risk factor to divorce or negatively affect their spouses or marital relationship in married patients. In our study, we aimed to examine the relation between neurological diseases and marital status, divorce, spouses' situation and marital relationship

Keywords Neurological diseases; marriage; health; life

$\ddot{\mathrm{O} z}$

Evlilik, insanların mutluluğunu ve yaşam süresini etkiler. Araștırmalar, evli insanların daha sağllkl, daha mutlu ve diğer insanlardan (bekar, boşanmış ve dul) daha uzun ömürlü oldukları fikrini desteklemektedir. Dünyada nörolojik hastalikların insidansı gün geçtikçe artmaktadır ve bu hastalkklar, hastaları, ailelerini ve toplumları etkileyebilmektedir. Bununla birlikte hastanın medeni hali, evlilik iliskisi ve es durumu hastalı̆̆ kabullenmesini ve hastalkla bas etmesini etkiler. Literatürde Amyotrofik Lateral Skleroz (ALS), Multipl Skleroz (MS), Alzheimer Hastalı̆̆ (AD), Parkinson Hastalı̆̆ (PD) ve inme gibi nörolojik hastalklarda, evli hastaları diğer hastalardan daha sağllklı ve uzun ömürlü olduğu ifade edilmektedir. Diğer yandan, evli hastalarda, MS ve epilepsi gibi hastalıklar boşanma için bir risk faktörü olabilir ya da eșlerini ve evlilik ilişkilerini olumsuz etkileyebilmektedir. Çalısmamızda nörolojik hastaliklar ile medeni durum, boșanma, eșlerin durumu ve evlilik arasındaki ilişkiyi incelemeyi amaçladık.




\section{INDRODUCTION}

Marriage is based on the association of a man and a woman, which affects people's health condition and lifetime. ${ }^{1,2}$ According to researches, it is stated that married people are healthier and happier, and they have longevity than other people (single, divorced and widowed). ${ }^{3,4}$

Neurological diseases have high incidence in the world among other disease. Strokes, Alzheimer Disease (AD), Parkinson's Disease (PD), Multiple Sclerosis (MS), epilepsy, migraine, Huntington's disease, Amyotrophic Lateral Sclerosis (ALS) are some of them. They cause high burden in patients, their families and societies. ${ }^{5,6}$

People with one neurological disease are marrying, have children or divorce as healthy people. Whether or not their disease has an impact on their marriage, if it has, how to have an effect or whether or not their marriage has an impact on their disease are curious topics. When reviewing literature, in neurological diseases, marital status, divorce, marital relationship, and spouses' situation are researched. ${ }^{3,7-10}$

\section{Marital Status and Neurological Disease}

ALS is one of progressive neurodegenerative diseases, which affects the motor neurons. ${ }^{10}$ One of prognostic factors for ALS is marital status. Married ALS patients have longer survival and lowest death rate for both sexes. Also, married ALS patients show good prognosis than unmarried patients. As the reason for this, spouses are instrumental and emotional support resources, helper to struggle with illness and provide advanced access to care.,11-13

MS is neurodegenerative, chronic demyelinating disease. It is seen in Central Nervous System (CNS). It causes physical disability and cognitive impairments. As a result, difficulty in acting independently, prevalent morbidity, depression, anxiety, and impairment in quality of life (QoL) are seen. ${ }^{7,14,15}$ In literature, married MS patients have low risk of depression. ${ }^{16,17}$ Also, married patients have low rate of receipt of behavioral medicine within one year of first neurology appointment compared to single and widowed. ${ }^{18}$ In another research, married MS patients have slower diseases progression, low severity of disease than singles. ${ }^{19}$ Also, married MS patients have higher score than single in QoL. ${ }^{20}$

Stroke is one of the common causes of death and disability around the world. Marital status is prognostic factor for stroke. In the literature, married people have low ratio of stroke prevalence, low risks of stroke and low severity of stroke than separated/divorced, single people. Also, married stroke patients are less likely to die after stroke. As the reason for this; marriage provides spousal support, early health seeking, encouragement of healthy behaviors and adherence to medication. However, in a research, unmarried, divorced, and widowed stroke patients have low mortality rate than married patients in one-week and onemonth stroke case. ${ }^{21-24}$

Epilepsy is a chronic and multifaceted neurological disorder. It has adverse effect on people's medical, social and economic life. These challenges affect patient's marital status. These patients have low marriage rate than other chronic illness and general population. This rate is low in male than women. Also as known, married individuals have high level life satisfaction, physical and psychological health. In the literature, married epilepsy patients have higher QoL. ${ }^{25-27}$ Because of marriage is a source to improve coping capacity and has positive effects on mood, married patients have high level life satisfaction and good health status than unmarried patients. ${ }^{28}$ In addition, being unmarried is found that it is sociodemographic risk factor for self-reported epilepsy. ${ }^{29}$ Also, for acceptance of illness, general view in literature, married epilepsy patients have high acceptance level. However, in a research, unmarried epilepsy patients have high acceptance level, widowed epilepsy patients have lowest acceptance level are found. ${ }^{30}$

$\mathrm{PD}$ is a neurodegenerative disease with motor and 
non-motor symptoms such as rigidity, bradykinesia, tremor, and postural instability, impairment of olfaction, vision sleep, salivation, sebaceous gland activity, mood and cognition. In studies on PD, marital status is also, examined. According to some research, being single in PD is a risk factor for depression and affects to depression score. Also, single in PD has low emotional well-being score. ${ }^{31-33}$ The treatment preference is influenced according to marital status since married patients are very likely to accept to treatment. $^{34}$

$\mathrm{AD}$ is a kind of dementia. Progressive impairment in memory and cognition is seen. ${ }^{35}$ Marital status is important for survival. Married patients have positive effect on survival. Therefore, married patients have lower mortality rate than single patients. This may be the reason; married patients have higher rate in using anti-dementia medication. In addition, single patients are more likely to have depression, delusion, elation and disinhibition..$^{36-39}$

\section{Divorce and Neurological Disease}

In cases where marriage cannot be carried out, divorce occurs. When look at the reason of divorce, poor problem-solving skills, displeasing personalities, marital history of marital discord, infertility, and maltreatment are seen. ${ }^{40}$ Whether neurological diseases have an effect on divorce or not is investigated. According to a research with Swedish MS patients, after diagnosis of MS, men with MS decide to divorce. In contrast to men with MS, there is no difference between women with MS and women general population. So, MS is risk factor of divorce for Swedish men. ${ }^{7}$ In a research with stroke patients, stroke affects marriage relationship is found. Another study says that according to several studies in the literature, stroke cause divorce or separation. ${ }^{41,42}$ The highest divorce rate is found in patients with stroke (pWS). In Korea, the rate of general population is more than twice as low as that in pWS. In Iran, this rate is $54.8 \%$. In a research in India, it supports that divorce rates of pWS is higher than general population. ${ }^{27,43-45}$

\section{Marital Relationship and Neurological Disease}

Marital relationship status, mental health and happiness have correlated each other. Marital relationship status and happiness determine mental health in general population. ${ }^{46}$ Whether neurological diseases have an effect on marital relationship status or not is investigated. According to a research in patients with ALS (pwALS), the pre-illness marital relationship predicts ongoing marital relationship for pwALS and their spouses. Also, psychological and social symptoms are more important than disease symptoms in marital relationship quality after diagnosis of ALS. ${ }^{8}$ In a research with MS patients, the patient's relationship with a spouse is damaged. Disease-adjustment challenges, difficulties in relationship and sexual functioning, and relationship dissolution may be reason of the damage in marital relationship. ${ }^{47}$ Regarding the epilepsy, it is found that it affects to marriage negatively. In a research with juvenile myoclonic epilepsy (JMS), patients with JMS have worse family relationship performance than control group. ${ }^{48,49}$ PD has also negative effect on marriage namely young-onset patients have marital discord than older patients. Caregiver-burden and depression, depression and low QoL scores in patients with PD can be reason of marriage discord. ${ }^{50,51}$ Marital relationship in AD is affected usually negative; but sometimes positively. Caregiving for a spouse with dementia negatively effects on marital satisfaction. In a research, from the perspective of patients, they choose minimizing their problems unlike their spouses. According to another research, after $\mathrm{AD}$ onset, men have worse affective marital satisfaction, women has stronger affective marital satisfaction. ${ }^{52,53}$

\section{Spouses' Situation and Neurological Disease}

Reduced quality of life, increased psychological distress, anxiety symptoms, depressive symptoms can be common features of spouses or caregivers with patients that have ALS, MS, stroke, epilepsy, PD and AD. ${ }^{52-65}$ Therefore, we can say that the neurological illness affects not only the patient but also their families. 


\section{CONCLUSION}

Marital status is a predictor of mental health and lifespan. Married people have mental health and long lifespan than single, divorced and widowed people. Whether the view is valid for neurological illness is examined. The general opinion supports the view. Also, being married decreases the rate of disease and provides good prognosis. In the emergence of this situation, being a source of social, emotional, and economical support for patients is effective factor.

Like marital status affects neurological disease, neurological disease affects marital status and marriage. Because of having a neurological disease, people can chose being single or married people can choose divorce as low marriage rate and high divorce rate in epilepsy. Also, neurological illness affects patient's marital relationship negatively. Their spouses show depressive and anxiety symptoms, low QoL, increased psychological stress. Briefly, there is a correlation between marriage and neurological disease.

\section{Acknowledgements}

The authors declare that they have no competing financial interests.

There is no funding source in the research. 


\section{Kaynaklar}

1. Gough EK. The Nayars and the definition of marriage. The Journal of the Royal Anthropological Institute of Great Britain and Ireland. 1959;89(1):23-34.

2. Spataro R, Volanti P, Lo Coco D, La Bella V. Marital status is a prognostic factor in amyotrophic lateral sclerosis. Acta Neurologica Scandinavica. 2017;136(6):624-30.

3. Meyer JM, Percheski C. Health behaviors and union dissolution among parents of young children: Differences by marital status. PloS one. 2017;12(8).

4. Myers JE, Madathil J, Tingle LR. Marriage satisfaction and wellness in India and the United States: A preliminary comparison of arranged marriages and marriages of choice. Journal of Counseling \& Development. 2005;83(2):183-90.

5. Feigin VL, Vos T. Global Burden of Neurological Disorders: From Global Burden of Disease Estimates to Actions. Neuroepidemiology. 2019;52(1-2):1-2.

6. Lindvall O, Kokaia Z. Stem cells for the treatment of neurological disorders. Nature. 2006;441(7097):1094-6.

7. Landfeldt E, Castelo-Branco A, Svedbom A, Löfroth E, Kavaliunas A, Hillert J. The longterm impact of multiple sclerosis on the risk of divorce. Multiple sclerosis and related disorders. 2018;24:145-50.

8. Atkins L, Brown RG, Leigh PN, Goldstein LH. Marital relationships in amyotrophic lateral sclerosis. Amyotrophic Lateral Sclerosis. 2010;11(4):344-50.

9. Smith LJ, Shaw RL. Learning to live with Parkinson's disease in the family unit: an interpretative phenomenological analysis of well-being. Medicine, Health Care and Philosophy. 2017;20(1):13-21,

10. Goutman SA, Nowacek DG, Burke JF, Kerber KA, Skolarus LE, Callaghan BC. Minorities, men, and unmarried amyotrophic lateral sclerosis patients are more likely to die in an acute care facility. Amyotrophic Lateral Sclerosis and Frontotemporal Degeneration. 2014;15(56):440-3.

11. Del Aguila M, Longstreth W, McGuire V, Koepsell T, Van Belle G. Prognosis in amyotrophic lateral sclerosis: a population-based study. Neurology. 2003;60(5):813-9.

12. Fegg MJ, Kögler M, Brandstätter M, Jox R, Anneser J, Haarmann-Doetkotte S, et al. Meaning in life in patients with amyotrophic lateral sclerosis. Amyotrophic Lateral Sclerosis. 2010;11(5):469-74.

13. Imaizumi Y. Mortality rate of amyotrophic lateral sclerosis in Japan: effects of marital status and social class, and geographical variation. Japanese journal of human genetics. 1986;31(2):101-11.

14. Mickens MN, Perrin PB, Aguayo A, Rabago B, Macías-Islas MA, Arango-Lasprilla JC. Mediational model of multiple sclerosis impairments, family needs, and caregiver mental health in Guadalajara, Mexico. Behavioural neurology. 2018;2018.

15. Carletto S, Borghi M, Francone D, Scavelli F, Bertino G, Cavallo M, et al. The efficacy of a Mindfulness Based Intervention for depressive symptoms in patients with Multiple Sclerosis and their caregivers: study protocol for a randomized controlled clinical trial. BMC neurology. 2016;16(1):7.

16. Simpson Jr S, Taylor KL, Jelinek GA, De Livera AM, Brown CR, O'Kearney E, et al. Associations of demographic and clinical factors with depression over 2.5-years in an international prospective cohort of people living with MS. Multiple sclerosis and related disorders. 2019;30:165-75.

17. Taylor KL, Hadgkiss EJ, Jelinek GA, Weiland TJ, Pereira NG, Marck CH, et al. Lifestyle factors, demographics and medications associated with depression risk in an international sample of people with multiple sclerosis. BMC psychiatry. 2014;14(1):327.

18. Greenberg B, Fan Y, Carriere L, Sullivan A. Depression and Age at First Neurology Appointment Associated with Receipt of Behavioral Medicine Services Within 1 Year in a Multiple Sclerosis Population. International journal of MS care. 2017;19(4):199-207.

19. Maryam Abbasi M, Nabavi SM, Seyed-Mohammad Fereshtehnejad M, Nikan Zerafatjou $M$, Vahid Shayegannejad M, Seyed Ehsan Mohammadianinejad M, et al. Risk factors of Multiple sclerosis and their Relation with Disease Severity: A Cross-sectional Study from Iran. Archives of Iranian medicine. 2016;19(12):852.

20. Baumstarck-Barrau K, Simeoni M-C, Reuter F, Klemina I, Aghababian V, Pelletier J, et al. Cognitive function and quality of life in multiple sclerosis patients: a cross-sectional study. BMC neurology. 2011;11(1):17

21. Sanuade OA, Dodoo FN-A, Koram K, Aikins Ad-G. Prevalence and correlates of stroke among older adults in Ghana: Evidence from the Study on Global AGEing and adult health (SAGE). PloS one. 2019;14(3).

22. Dupre ME, Lopes RD. Marital history and survival after stroke. Journal of the American Heart Association. 2016;5(12):e004647.

23. Liu Q, Wang X, Wang Y, Wang C, Zhao X, Liu L, et al. Association between marriage and outcomes in patients with acute ischemic stroke. Journal of neurology. 2018;265(4):942-8.

24. Andersen K, Olsen T. Stroke case-fatality and marital status. Acta Neurologica Scandina- vica. 2018;138(4):377-83

25. Saada F, Wang ZS, Bautista RED. In focus: The everyday lives of families of adult individuals with epilepsy. Epilepsy \& Behavior. 2015;50:10-3.

26. Tedrus GMAS, Fonseca LC, Pereira RB. Marital status of patients with epilepsy: factors and quality of life. Seizure. 2015;27:66-70.

27. Kinariwalla $N$, Sen $A$. The psychosocial impact of epilepsy on marriage: a narrative review. Epilepsy \& Behavior. 2016;63:34-41.

28. Elliott JO, Charyton C, Sprangers $P, L u$ B, Moore JL. The impact of marriage and social support on persons with active epilepsy. Epilepsy \& behavior. 2011;20(3):533-8.

29. Ferro MA. A population-based study of the prevalence and sociodemographic risk factors of self-reported epilepsy among adults in the United Kingdom. Seizure. 2011;20(10):784-8.

30. Staniszewska A, Religioni U, Dąbrowska-Bender M. Acceptance of disease and lifestyle modification after diagnosis among young adults with epilepsy. Patient preference and adherence. 2017;11:165.

31. Dobkin RD, Rubino JT, Allen LA, Friedman J, Gara MA, Mark MH, et al. Predictors of treatment response to cognitive-behavioral therapy for depression in Parkinson's disease. Journal of Consulting and Clinical Psychology. 2012;80(4):694.

32. Kadastik-Eerme L, Rosenthal M, Paju T, Muldmaa M, Taba P. Health-related quality of life in Parkinson's disease: a cross-sectional study focusing on non-motor symptoms. Health and quality of life outcomes. 2015;13(1):83.

33. Cui S-S, Du J-J, Fu R, Lin Y-Q, Huang P, He Y-C, et al. Prevalence and risk factors for depression and anxiety in Chinese patients with Parkinson disease. BMC geriatrics. 2017;17(1):270

34. Li W, Ng HL, Li W, Piano AN, Karim SA, Tay KY, et al. Treatment Preferences at the End-ofLife in P arkinson's Disease Patients. Movement disorders clinical practice. 2016;3(5):483-9.

35. Mancino R, Martucci A, Cesareo M, Giannini C, Corasaniti MT, Bagetta G, et al. Glaucoma and Alzheimer disease: one age-related neurodegenerative disease of the brain. Current neuropharmacology. 2018;16(7):971-7.

36. Dijkstra A, Sipsma DH, Dassen TW. Care dependency and survival among female patients with Alzheimer's disease: a two-year follow-up. Croatian medical journal. 1998;39:365-70.

37. Steenland K, MacNeil J, Vega I, Levey A. Recent trends in Alzheimer's disease mortality in the United States, 1999-2004. Alzheimer disease and associated disorders. 2009;23(2):165.

38. Hernandez S, McClendon MJ, Zhou X-HA, Sachs M, Lerner AJ. Pharmacological treatment of Alzheimer's disease: effect of race and demographic variables. Journal of Alzheimer's Disease. 2010;19(2):665-72.

39. Apostolova LG, Di LJ, Duffy EL, Brook J, Elashoff D, Tseng C-H, et al. Risk factors for behavioral abnormalities in mild cognitive impairment and mild Alzheimer's disease. Dementia and geriatric cognitive disorders. 2014;37(5-6):315-26.

40. McNulty JK, Widman L. Sexual narcissism and infidelity in early marriage. Archives of sexual behavior. 2014;43(7):1315-25.

41. Mapulanga M, Nzala S, Mweemba C. The Socio-economic Impact of Stroke on Households in Livingstone District, Zambia: A Cross-sectional Study. Annals of medical and health sciences research. 2014;4(8):123-7.

42. Daniel K, Wolfe CD, Busch MA, McKevitt C. What are the social consequences of stroke for working-aged adults? A systematic review. Stroke. 2009;40(6):e431-e40.

43. Kim M-K, Kwon O-Y, Cho Y-W, Kim Y, Kim S-E, Kim H-W, et al. Marital status of people with epilepsy in Korea. Seizure. 2010;19(9):573-9.

44. Riasi H, Sanati AR, Ghaemi K. The stigma of epilepsy and its effects on marital status. SpringerPlus. 2014;3(1):762.

45. Agarwal P, Mehndiratta M, Antony A, Kumar N, Dwivedi R, Sharma P, et al. Epilepsy in India: nuptiality behaviour and fertility. Seizure. 2006;15(6):409-15.

46. Ahmadi Forooshany SH, Yazdkhasti F, Safari Hajataghaie S, Nasr Esfahani MH. Infertile individuals' marital relationship status, happiness, and mental health: a causal model. Int $J$ Fertil Steril. 2014;8(3):315-24.

47. Tompkins SA, Roeder JA, Thomas JJ, Koch KK. Effectiveness of a relationship enrichment program for couples living with multiple sclerosis. International journal of MS care. 2013;15(1):27-34.

48. Amudhan S, Gururaj G, Satishchandra P. Epilepsy in India II: Impact, burden, and need for a multisectoral public health response. Annals of Indian Academy of Neurology. 2015; 18(4):369.

49. Moschetta S, Valente KD. Impulsivity and seizure frequency, but not cognitive deficits, impact social adjustment in patients with juvenile myoclonic epilepsy. Epilepsia. 2013;54(5):866-70.

50. Schrag A, Hovris A, Morley D, Quinn N, Jahanshahi M. Caregiver-burden in Parkinson's disease is closely associated with psychiatric symptoms, falls, and disability. Parkinsonism e 
Sakarya Med J 2020;10(4):705-710

AYDIN et al., Neurological Disease and Marriage

related disorders. 2006;12(1):35-41.

51. Schrag A, Hovris A, Morley D, Quinn N, Jahanshahi M. Young-versus older-onset Parkinson's disease: impact of disease and psychosocial consequences. Movement disorders: official journal of the Movement Disorder Society. 2003;18(11):1250-6.

52. Simonelli C, Tripodi F, Rossi R, Fabrizi A, Lembo D, Cosmi V, et al. The influence of caregiver burden on sexual intimacy and marital satisfaction in couples with an Alzheimer spouse. International Journal of Clinical Practice. 2008;62(1):47-52.

53. Ascher EA, Sturm VE, Seider BH, Holley SR, Miller BL, Levenson RW. Relationship satisfaction and emotional language in frontotemporal dementia and Alzheimer's disease patients and spousal caregivers. Alzheimer disease and associated disorders. 2010;24(1):49.

54. Grabler MR, Weyen U, Juckel G, Tegenthoff M, Mavrogiorgou-Juckel P. Death anxiety and depression in amyotrophic lateral sclerosis patients and their primary caregivers. Frontiers in neurology. 2018;9:1035.

55. Galvin M, Corr B, Madden C, Mays I, McQuillan R, Timonen V, et al. Caregiving in ALS- $a$ mixed methods approach to the study of burden. BMC palliative care. 2016;15(1):81.

56. Rakhshan M, Ganjalivand S, Zarshenas L, Majdinasab N. The Effect of Collaborative Care Model-Based Intervention on Hope in Caregivers and Patients with Multiple Sclerosis: A Randomized Controlled Clinical Trial. International journal of community based nursing and midwifery. 2018;6(3):218

57. McKenzie T, Quig ME, Tyry T, Marrie RA, Cutter G, Shearin E, et al. Care partners and multiple sclerosis: differential effect on men and women. International journal of MS care. 2015;17(6):253-60.
58. Costa TFd, Gomes TM, Viana LRdC, Martins KP, Costa KNdFM. Acidente vascular encefálico: características do paciente e qualidade de vida de cuidadores. Revista Brasileira de Enfermagem. 2016;69(5):933-9.

59. Lutz BJ, Young ME, Creasy KR, Martz C, Eisenbrandt L, Brunny JN, et al. Improving stroke caregiver readiness for transition from inpatient rehabilitation to home. The Gerontologist. 2017;57(5):880-9

60. Penovich PE, Buelow J, Steinberg K, Sirven J, Wheless J. Burden of Seizure Clusters on Patients With Epilepsy and Caregivers. The neurologist. 2017;22(6):207-14.

61. Karakis I, Cole AJ, Montouris GD, San Luciano M, Meador KJ, Piperidou C. Caregive burden in epilepsy: determinants and impact. Epilepsy research and treatment. 2014;2014.

62. Baik JS, Kim J-S, Koh S-B, Cho JW, Lee PH, Ma H-I, et al. Patients and their caregivers' burdens for Parkinson's disease in Korea. Journal of movement disorders. 2017;10(3):109.

63. Tessitore A, Marano P, Modugno N, Pontieri FE, Tambasco N, Canesi M, et al. Caregiver burden and its related factors in advanced Parkinson's disease: data from the PREDICT study. Journal of neurology. 2018;265(5):1124-37.

64. Alqahtani MS, Alshbriqe AA, Awwadh AA, Alyami TA, Alshomrani MS, Alhazzani A. Pre valence and Risk Factors for Depression among Caregivers of Alzheimer's Disease Patients in Saudi Arabia. Neurology research international. 2018;2018.

65. Goren A, Montgomery W, Kahle-Wrobleski K, Nakamura T, Ueda K. Impact of caring for persons with Alzheimer's disease or dementia on caregivers' health outcomes: findings from a community based survey in Japan. BMC geriatrics. 2016;16(1):122. 